\title{
Meningkatkan Literasi Masyarakat Bangko Kanan dalam Menghadapi Pandemi COVID-19
}

\author{
Campin Veddayana ${ }^{1}$, Fenny Anita ${ }^{2}$, Hardiana Rizka Puspita Ningrum $^{3}$ \\ ${ }^{1}$ Fakultas Teknik, Universitas Abdurrab \\ ${ }^{2}$ Fakultas Kedokteran dan Ilmu Kesehatan, Universitas Abdurrab \\ ${ }^{3}$ Fakultas Kedokteran, Universitas Abdurrab \\ email: Campin.veddayana@univrab.ac.id
}

\begin{abstract}
In facing the COVID-19 pandemic, a community structure with a critical and creative mindset and perspective is needed. This will be realized if people have good literacy regarding the COVID-19 outbreak. Meanwhile, the literacy capacity of the people in the Bangko Kanan area is still considered weak. This can be seen from the public who are still indifferent to health protocols and also excessive panic over information related to the Corona virus that is widely circulating in the community. Therefore, counseling related to the COVID-19 pandemic, especially in the working area of the Puskesmas Bangko Kanan, Rokan Hilir district, was carried out to increase public literacy so that they are more concerned with health protocols and are critical of the information presented by the media.
\end{abstract}

Keywords: Literacy, COVID-19, Health Protocol

\begin{abstract}
Abstrak
Dalam menghadapi masa pandemi COVID-19 dibutuhkan tatanan masyarakat dengan pola pikir dan pandangan yang kritis dan kreatif. Hal tersebut akan terwujud jika masyarakat memiliki literasi yang baik terkait wabah COVID-19. Sementara itu, kemampuan literasi masyarakat di wilayah Bangko Kanan dinilai masih lemah. Hal ini terlihat dari masyarakat yang masih acuh terhadap protokol kesehatan dan juga kepanikan yang berlebihan terhadap informasi terkait virus Corona yang beredar luas di masyarakat. Oleh sebab itu, penyuluhan terkait pandemi COVID-19 khususnya di wilayah kerja Puskesmas Bangko Kanan, kabupaten Rokan Hilir ini dilaksanakan untuk meningkatkan literasi masyarakat agar lebih peduli terhadap protokol kesehatan dan bersikap kritis terhadap informasi yang disuguhkan media.
\end{abstract}

Kata Kunci : Literasi, COVID-19, Protokol Kesehatan

\section{PENDAHULUAN}

Corona Virus Disease (COVID-19) telah mewabah hampir ke seluruh dunia dengan tingkat keparahan yang mengkhawatirkan. Oleh sebab itu mulai tanggal 11 Maret 2020 keadaan ini dinyatakan sebagai pandemi oleh WHO [1]. Sejak saat itu, kota Wuhan telah mengambil langkah-langkah yang belum pernah terjadi sebelumnya dalam menanggapi wabah tersebut, seperti penutupan sekolah dan tempat kerja. Selain itu Wuhan juga melakukan peningkatan kemampuan literasi, khususnya dibidang kesehatan. Sebab seseorang dengan literasi yang rendah diketahui lebih rentan terhadap tertular COVID-19 [2].

Literasi secara umum diartikan sebagai sebuah kemampuan seseorang dalam mengolah dan memahami informasi saat melakukan proses membaca dan menulis. Sebagaimana dinyatakan dalam Kamus Oxford yaitu Literacy is ability to read and write. Artinya, literasi adalah kemampuan membaca dan menulis. 
Sementara itu, information is fact to talk, heart and discovered about somebody/something. Artinya, fakta tentang seseorang atau sesuatu yang dibicarakan, didengar, dan dikemukakan. Maka berdasarkan penjelasan diatas, literasi dapat diartikan sebagai kemampuan seseorang mengolah dan memahami sesuatu yang sedang dibicarakan, didengarkan, dan dikemukakan (fakta). Dalam perkembangannya, literasi memiliki arti yang luas sehingga ada bermacam-macam jenis literasi, misalnya literasi komputer (computerliteracy), literasi media (media literacy), literasi teknologi (technology literacy), literasi ekonomi (economy literacy), literasi informasi (information literacy), dan literasi moral (moral literacy), literasi kesehatan (health literacy) [3].

Kebutuhan akan literasi dalam menumbuhkan kesadaran terhadap bahaya COVID-19 membutuhkan penggunaan informasi yang cukup bagi masyarakat dunia termasuk Indonesia. Pengetahuan akan kesehatan perlu disebarluaskan kepada seluruh lapisan masyarakat. Perhatian lebih perlu dicurahkan khususnya kepada masyarakat dengan tingkat literasi kesehatan yang rendah dalam mengevaluasi informasi kesehatan secara. Dengan adanya wabah COVID-19 ini masyarakat seharusnya menguatkan kemampuan literasi yang dimiliki [4].

Ketika masyarakat tidak memahami detailnya informasi, maka informasi yang salah akan menyebar dengan cepat dan masyarakat dapat membuat keputusan yang buruk sehingga berdampak buruk terhadap kesehatannya dan keselamatan masyarakat banyak. Selain itu informasi yang salah selama masa krisis kesehatan dapat menyebarkan paranoia, ketakutan, dan stigmatisasi. Hal ini juga dapat menyebabkan orang menjadi tidak terlindungi dengan baik atau lebih rentan terhadap virus. Dalam kondisi seperti ini, informasi yang tepat sangat diperlukan bagi setiap individu. Sehingga, setiap orang menjadi waspada dan menerapkan pencegahan protokol kesehatan untuk mencegah COVID-19 [5].

Indonesia merupakan negara yang berpenduduk dengan tingkat literasi yang masih rendah. Hal tersebut diungkapkan UNESCO bahwa Indonesia menduduki peringkat 60 dari 61 negara di dunia pada level literasi baca [6]. Survei yang menyatakan minat baca masyarakat Indonesia terendah kedua di dunia, masih tergolong angka rata-rata secara keseluruhan.

Berawal dari berbagai persoalan tersebut maka perlu dilakukan kegiatan yang dapat meningkatkan literasi masyarakat agar siap menghadapi pandemi COVID-19. Kegiatan akan dilakukan di wilayah kerja Puskesmas Bangko Kanan. Lokasi Puskesmas ini berada di Desa Bangko Kanan, Kecamatan Bangko Pusako, Kabupaten Rokan Hilir, Riau. Wilayah kerja Puskesmas tersebut dipilih karena setelah dilakukan studi pendahuluan diketahui bahwa pengetahuan masyarakat di wilayah kerja Puskesmas Bangko Kanan mengenai COVID-19 masih kurang. Masyarakat masih belum menjalankan protokol kesehatan seperti yang dianjurkan oleh pemerintah. Selain itu berdasarkan data yang diperoleh dari pihak Puskesmas Bangko Kanan disebutkan bahwa mayoritas masyarakat di wilayah kerja Puskesmas Bangko Kanan mengalami panik yang berlebihan terkait kondisi yang terjadi saat ini. Masyarakat menerima semua informasi yang diperoleh tanpa mengkritisinya terlebih dahulu. Oleh sebab itu kegiatan yang akan dilaksanakan adalah penyuluhan untuk mengedukasi masyarakat Bangko Kanan terkait COVID-19 dan memberikan pemahaman kepada masyarakat tentang betapa pentingnya kemampuan berliterasi di kondisi saat ini. 


\section{METODE PENGABDIAN}

Adapun kegiatan pengabdian, teknik menyelesaikan permasalahan, dan alat ukur ketercapaian akan dijabarkan sebagai berikut.

\section{Program Kerja}

\section{a. Penyuluhan}

Penyuluhan dilakukan dengan cara mengumpulkan masyarakat dari masingmasing desa di wilayah kerja Puskesmas Bangko Kanan. Berikut Penyuluhan ini dilakukan pada hari Senin 7 September 2020 pukul 10:00-12:00 WIB di Rumah Bidan Desa di Bangko Kanan. Susunan acara:

a) Pembukaan oleh bidan desa.

b) Pembacaan do'a.

c) Pengenalan anggota pengabdian yang akan melakukan penyuluhan

d) Kata sambutan dari pelaksana kegiatan.

e) Pengisian daftar hadir oleh peserta penyuluhan.

f) Penyuluhan mengenai COVID-19 dan peran literasi di kondisi saat ini.

g) Diskusi dan tanya jawab.

h) Pembagian kuesioner.

i) Penutupan oleh bidan desa.

j) Makan bersama

b. Penempelan Poster

Penempelan poster berisikan edukasi terkait COVID-19. Penempelan poster tersebut diharapkan dapat menjadi media informasi terkait COVID-19 yang bisa dibaca kapanpun dan oleh siapapun sehingga pemahaman masyarakat mengenai COVID-19 akan bertambah. Penempelan poster dilakukan pada hari Senin 7 September 2020 pukul 13:3017:00 di tempat-tempat umum di wilayah kerja Puskesmas Bangko Kanan.

\section{Teknik Menyelesaikan Masalah}

Teknik yang diterapkan dalam pengenalan COVID-19 melalui literasi ini adalah dengan cara memberikan edukasi melalui penyuluhan terlebih dahulu, kemudian memberikan lembar kuesioner yang berisi beberapa pertanyaan terkait materi penyuluhan serta menanyakan langsung kepada setiap masyarakat terkait kendala yang dialami dikondisi saat ini sehingga membuat masyarakat kurang mengetahui tentang COVID-19 dan tidak dilaksanakannya protokol kesehatan. Setelah tanya jawab dan mendengar kendala setiap masyarakat, maka kami memberikan solusi dengan cara menyarankan beberapa hal sesuai dengan pengetahuan keilmuan yang dimiliki, seperti kendala terkait bingungnya masyarakat tentang kebenaran COVID-19 karena ada beberapa orang yang menyebutkan bahwa COVID-19 itu bohong sehingga kami memberi solusi untuk tidak mempercayai informasi dari sumber tidak jelas dan hanya boleh mempercayai informasi yang berasal dari sumber yang jelas seperti pemerintah. Selain itu kami terkait kendala yang tidak dapat diselesaikan oleh tim pengabdi seperti tidak adanya televisi atau handphone yang dimiliki oleh masyarakat sehingga ketidaktahuan terhadap informasi yang beredar, maka kami akan melakukan diskusi lebih lanjut kepada pihak Puskesmas Bangko Kanan untuk memberikan penyuluhan dan edukasi secara rutin terkait perkembangan COVID-19 untuk menyentuh masyarakatmasyarakat yang tidak mempunyai akses untuk memperoleh informasi sehingga ketidaktahuan tentang COVID-19 pada masyarakat di wilayah kerja Puskesmas Bangko Kanan akan bertambah. Disamping itu kami juga melakukan penempelan poster yang berisi informasi terkait COVID-19 di tempat-tempat umum, hal ini tentunya juga akan membantu masyarakat dalam memahami tentang COVID-19.

\section{Alat Ukur Ketercapaian}

Setelah memberikan edukasi tentang mengenal COVID-19 melalui literasi, maka kami memberikan beberapa evaluasi tentang materi yang sudah diberikan dengan membagikan lembar kuesioner 
yang berisi beberapa pertanyaan kepada masyarakat di wilayah kerja Puskesmas Bangko Kanan. Kuesioner berisi 11 pertanyaan terkait materi penyuluhan mengenai COVID-19 dan berliterasi. Pertanyaan yang digunakan sebagai alat ukur ketercapaian adalah sebagai berikut.

1. Apakah saudara sudah memahami mengenai Covid19 ?

A. YA

B. TIDAK

2. Apakah saudara sudah tau mengenai gejala apa saja yang muncul pada orang yang terinfeksi Covid-19?

A. YA

B. TIDAK

3. (Pertanyaan ini berhubungan dengan pertanyaan nomor 2, jika saudara menjawab IYA silahkan isi pertanyaan ini, tetapi apabila saudara menjawab TIDAK silahkan kosongkan pertanyaan ini)

Sebutkan 3 gejala umum dari Covid-19!

Jawab :

4. Manakah yang lebih berisiko untuk terinfeksi Covid-19 antara orang dengan penyakit penyerta atau tidak dengan penyakit penyerta?

A. Orang dengan penyakit penyerta

B. Orang tidak dengan penyakit penyerta

5. Sebutkan salah 1 cara penularan Covid-19!

Jawab :

6. Apakah menggunakan masker merupakan salah 1 cara pencegahan Covid-19?

A. YA

B. TIDAK

7. Apakah saudara sudah memahami tentang

\begin{tabular}{|c|}
\hline \\
\hline $\begin{array}{l}\text { 8. Apakah saudar } \\
\text { mpu untuk meningkatka } \\
\text { mampuan berliterasi gun } \\
\text { mbantu diri anda da } \\
\text { gkungan agar terhinda }\end{array}$ \\
\hline $\begin{array}{l}\text { 9. Hal apa yang akan } \\
\text { saudara lakukan untuk } \\
\text { meningkatkan kemampuan } \\
\text { berliterasi yang saudara } \\
\text { miliki? Silahkan tulis.. } \\
\text { Jawab: }\end{array}$ \\
\hline $\begin{array}{l}\text { 10. Apakah penyu } \\
\text { mengenai Covid-19 } \mathrm{n} \\
\text { literasi ini mem } \\
\text { saudara dalam mem } \\
\text { Covid-19? Jika Iya, } \\
\text { tuliskan seb } \\
\text { membantunya penyu } \\
\text { ini terhadap diri sa }\end{array}$ \\
\hline
\end{tabular}

\section{HASIL DAN PEMBAHASAN}

\section{Potensi Pengembangan}

Pengenalan COVID-19 melalui literasi pada masyarakat di wilayah kerja Puskesmas Bangko Kanan merupkan judul pengabdian masyarakat kelompok 6 . Pengabdian masyarakat ini bertujuan membuat masyarakat di wilayah kerja Puskesmas Bangko Kanan lebih memahami mengenai COVID-19 dan menumbuhkan kesadaran masyarakat tentang pentingnya berliterasi di kondisi saat ini. Pada akhirnya diharapkan hal tersebut dapat membantu pemerintah dalam memutus rantai penyebaran COVID-19.

Pada kondisi saat ini setiap informasi akan dengan mudah didapatkan seperti di media sosial, maka kami berharap dengan 
adanya pengabdian ini, masyarakat lebih mampu untuk menumbuhkan kemampuan berliterasi. Hal tersebut dikarenakan semua informasi yang disuguhkan saat ini beredar bebas dimana saja, terutama terkait COVID-19. Informasi yang disugukan tentunya tidak akan ada manfaatnya apabila masyarakat masih memiliki kemampuan berliterasi yang rendah, atau bahkan tidak sama sekali mempunyai minat berliterasi. Mengingat kondisi yang terjadi saat ini, bukan tidak mungkin hal tersebut akan semakin memperburuk keadaan yang terjadi. Seperti ketidaktahuan masyarakat mengenai COVID-19, kesalahpahaman arti oleh masyarakat terkait COVID-19, mempercayai semua informasi yang beredar tanpa sumber yang jelas, tidak dilaksanakannya protokol kesehatan karena tidak pahamnya masyarakat akan pentingnya menerapkan protokol kesehatan, dan masih banyak lagi dampak buruknya dari lemahnya kemampuan dan keinginan berliterasi.

\section{Solusi Pengembangan}

Memberikan penyuluhan tentang pengenalan COVID-19 melalui literasi dan melakukan penempelan poster terkait COVID-19 di berbagai tempat umum di wilayah kerja Puskesmas Bangko Kanan menjadi bahan dan salah satu solusi meningkatkan pengetahuan serta pemahaman masyarakat setempat terkait COVID-19 dan dapat menumbuhkan keinginan atau kemampuan berliterasi masyarakat yang nantinya diharapkan dapat ikut serta membantu pemerintah dalam memutus rantai penyebaran COVID-19.

\section{Tingkat Ketercapaian Sasaran Program}

Program kerja yang dilakukan sudah mencapai sasaran program yang diinginkan, hal tersebut dapat dilihat dari mampunya masyarakat di wilayah kerja Puskesmas Bangko Kanan menjawab semua pertanyaan di kuesioner tentang semua materi penyuluhan baik mengenai COVID-19 maupun kemampuan berliterasi dan setelah dilihat hampir dari semua masyarakat yang diberikan penyuluhan memberikan jawaban yang benar. Selain itu telah tertempelnya poster terkait COVID-19 di tempat-tempat umum yang bisa menjadi media informasi terkait COVID-19 yang bisa dibaca kapanpun dan oleh siapapun sehingga pemahaman masyarakat mengenai COVID-19 akan bertambah.

Berikut hasil perolehan dari semua jawaban masyarakat di wilayah kerja Puskesmas Bangko Kanan pada kuesioner yang sudah dibagikan :

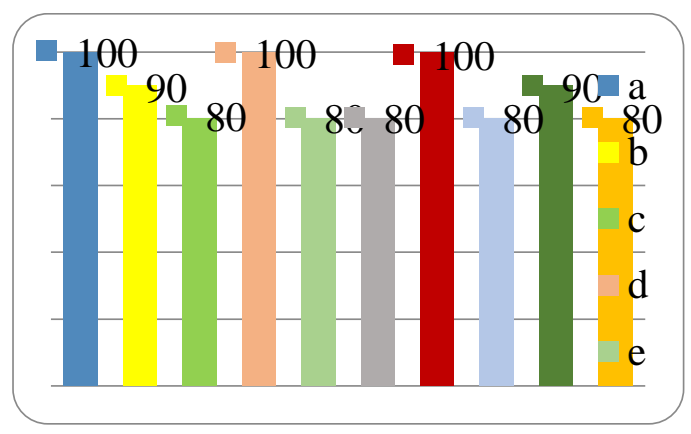

Gambar 1. Hasil Kuesioner Penyuluhan

Berdasarkan gambar diatas dapat dilihat bahwa dari 10 poin pertanyaan yang sudah dijawab tidak ada pertanyaan yang tidak bisa dijawab oleh masyarakat. Ratarata nilai dari 10 pertanyaan tersebut adalah 88, ini artinya lebih dari setengah masyarakat dapat memahami terkait materi yang sudah dijelaskan. Maka dapat disimpulkan bahwa sasaran pada pengabdian masyarakat ini sudah tercapai

\section{SIMPULAN}

Dari kegiatan pengabdian yang telah dilakukan, maka dapat diambil kesimpulan sebagai berikut.

1. Masyarakat di wilayah kerja Puskesmas Bangko Kanan setelah diberikan penyuluhan cukup mampu untuk mamahami terkait informasi COVID19 yang sudah disampaikan.

2. Masyarakat di wilayah kerja Puskesmas Bangko Kanan sudah mulai mengerti 
tentang betapa pentingnya mempunyai kemampuan berliterasi di kondisi saat ini.

Masyarakat di wilayah kerja Puskesmas Bangko Kanan sudah memahami mengenai semua informasi terkait COVID-19 yang telah dipaparkan dan manfaat dari memiliki kemampuan berliterasi yang baik serta mereka memnyatakan akan meningkatkan kemampuan berliterasi dengan membaca informasi setiap harinya minimal 10 menit dan akan selalu memilih serta memilah semua informasi terutama terkait COVID19.

\section{UCAPAN TERIMA KASIH}

Terima kasih kepada LPPM Universitas Abdurrab yang telah mengizinkan kegiatan pengabdian ini. Terima kasih kepada masyarakat Desa Bangko Kanan, Kabupaten Rokan Hilir.

\section{DAFTAR PUSTAKA}

[1] J. Bedford et al., "COVID-19: Towards Controlling of a Pandemic," Lancet, vol. 395, no. 10229, pp. 1015-1018, 2020.

[2] K. Prem et al., "The Effect of Control Strategies to Reduce Social Mixing on Outcomes of the COVID-19 Epidemic in Wuhan, China: a Modelling Study," Lancet Public Heal., 2020.

[3] T. Septiantono, "Konsep Dasar Literasi Informasi," Jakarta Univ. Terbuka.[Online] Diakses dari http//repository. ut. ac. id/4198/1/PUST4314-M1. pdf pada, pp. 10-25, 2017.

[4] M. F. (Universitas N. J. Syah, R. A. J. Winarno, and D. G. Ahya, "Literasi Kesehatan dalam Penanggulangan Pandemik COVID-19," J. AKRAB, vol. XI, no. 7, pp. 70-76, 2020.

[5] A. Athena, E. Laelasari, and T. Puspita, "Pelaksanaan Disinfeksi dalam Pencegahan Penularan
Covid-19 dan Potensi Risiko terhadap Kesehatan di Indonesia," J. Ekol. Kesehat., vol. 19, no. 1, pp. 1-20, 2020.

[6] E. Nugrahini, "Gerakan Literasi untuk Tumbuhkan Budaya Literasi," Jendela Pendidik. dan Kebud., vol. 6, pp. 4-21, 2016. 